\title{
Women Participation in Nigerian Trade Union Movement: A Strategic and Socio-Psychological Viewpoint
}

\author{
Francis Chuks Anyim \\ Department of Industrial Relations and Personnel Management \\ University of Lagos, Akoka-Yaba, Lagos State, Nigeria \\ E-mail: chucksanyim2004@yahoo.com \\ Owolabi Lateef Kuye (Corresponding author) \\ Department of Business Administration \\ University of Lagos, Akoka-Yaba, Lagos State, Nigeria \\ E-mail: labikuye@yahoo.com \\ Joy Onyinyechi Ekwoaba \\ Department of Industrial Relations and Personnel Management \\ University of Lagos, Akoka-Yaba, Lagos State, Nigeria \\ E-mail: ekwoaba2002@yahoo.com
}

Received: November17, 2011 Accepted: November 282011 Published: January 1, 2012

doi:10.5296/jmr.v4i1.1088～URL: http://dx.doi.org/10.5296/jmr.v4i1.1088

\begin{abstract}
The Trade Union Movement is an organization that champions the cause(s) of workers and also serves as a countervailing force against the awesome powers and the exploitative tendencies of the capitalist or employers within the employment relations. The organization has both male and female employees in its rank and file membership and cut across various occupational groups and industries. However, there is a general notion that women participation in Nigerian Trade Union Movement currently is at low ebb. This paper examines participation of women in trade unionism in Nigeria - the nature of the apparatus
\end{abstract}




\section{Macrothink}

Journal of Management Research

ISSN 1941-899X 2012, Vol. 4, No. 1: E17

and mechanism of trade unionism, political environment or terrain, dual role played by women, patriarchy, marginalization through male domination, and religious constraints amongst others. The findings of this paper revealed that women participation in trade union movement is a healthy development and should be encouraged in all its ramifications but added that women should be allowed to hold administrative positions (secretaryship, treasureship, trusteeship and ex-officio). In a nutshell, women should be restricted from activities laced with militancy which is a very prevalent mode and operational tool in modern day trade unionism whether in the public or private sector.

Keywords: Nigeria, Women, Trade union movement, Strategic, Socio-psychological Viewpoint 


\section{Introduction}

Despite sustained hostility from some employers and occasional state repression coupled with membership passiveness and indifference of the public, trade unions remain an enduring institution in the employment relations. This much is admitted by Mulvey (1978) as he acknowledges that in most of the industrial countries the most pervasive institution is the trade union movement. Trade unions developed in response to challenges thrown up by the new organization of work and production built around the factory system that emerged as the new centre of economic activities after the industrial revolution in the $17^{\text {th }}$ and early $18^{\text {th }}$ centuries. They emerged without the prompting of governments and employers and also as independent organizations of workers without any legal backing. They first emerged in England and it was not until 1824 that the legal encumbrance was removed.

According to Otobo (1996), unions carry on many different activities. Most visible to the average member are those which produce direct benefit-negotiations, grievance handling, community service, and uncertain trades, job search or referral. Another type of activity arises from the internal politics of the union. It consists of elections, meetings, conventions and similar forums in which members participate in governing the union. But to be effective a union must build and maintain itself as on organization. This entails bringing in members through organizing and keeping the union running smoothly through union administration and effective internal communications. Otobo (1996) further states that trade unions occupy a special position because they are organizations of wage earners, workers, and quite often they are about the only other group in society that has as its main duty or responsibility to react to the industrial and socio-economic policies of government and of private employers and try to protect the interest of members within individual enterprises. The industrial trade unions are by their nature and structure basically democratic institutions whatever, their other failures. And within and outside of their executives and central working committees, state or zonal branches, members can always propose and oppose any line of action. From the foregoing, union leaders cannot be seen or taken as dictators that can impose an unpopular position or stance on members. Members would either throw them out, or when not possible because of union constitutional provisions can bypass such leaders. Okogwu (1996) also agrees with Otobo when he asserts that in addition to increasing wages and improving conditions of employment, trade unions provide workers both with protection against arbitrary management decisions and with a voice at the place of work and in the political arena.

Like its counterparts in different parts of the world, the Nigerian trade union movement has a glorious past, a past characterized by robust struggles and principled opposition to state policies that are inimical to the interests of the working people. It is also a past that was characterized by conscious efforts at mobilizing the rank-and-file members as a bulwark against state repression. The past equally witnessed the building of alliances between the trade union movement and various elements and organizations within the larger labour movement. All these constituted the pillars of strength of the trade union movement (Adewumi, 1997). 
Nigerian Trade Union movement comprises a variety of unions that represent the specific interest of workers. They engage in struggling for the rights and welfare of workers, specifically, for decent wages and improved conditions of service, where negotiations fail to achieve the desired result, trade unions are noted for resorting to radical action - such as stay at homes, work to rule, demonstrations and street protests - which are capable of not only grounding the particular production process but, sometimes and more crucially, the economy (Tar, 2009). They have become the voice of the voiceless, platform for the unheard and downtrodden, and the hope of the masses (Imhonopi and Urim, 2011). Thus, there is no doubt that trade unions in Nigeria have come a long way in enhancing the economic well-being of its members. It has even passed through the burning and fiery flame doing so (Ademiluyi and Imhonopi, 2010).

However, there has been low participation of women in trade unionism in Nigeria. Recent research suggests that women are less competitive and hierarchical than men (Schwartz and Rubel 2005; Kaminski and Yakura, 2008). Hence the need to examine the extent of women participation in trade unionism in Nigeria.

Women all over the world are generally referred to as weaker sex. This gives the impression that women are powerless or in another word not as strong as men. Due to this perception, certain jobs and functional duties are generally regarded as not for women. This impression, no doubt has affected women education and aspirations. According to Odi (2010), during the colonial period, education curricula emphasized religious instruction and clerical skills for boys and domestic science for girls. Besides, there was the perception that women needed to be educated only to be good housewives.

By nature, women are responsible for birth, nurturing and upbringing of children, who will grow to become adults of tomorrow. Men regard the kitchen as the right place for women. However, modern trends have shown and indicate that women after all are not as weak as may be perceived in some quarters.

In recent times, women have now combined the kitchen job with office and factory jobs. Consequently, the role of women in helping to build a good society should not be under-rated. It is therefore, not surprising that today few enterprising women who felt they can compete with men are fast breaking new grounds in terms of securing jobs, taking part in politics e.g. Mrs. Indira Gahandi of India, late Golda Mier of Isreal; Mrs. Margaret Thatcher, the former Prime Minister of Great Britain. In Nigeria, women like late Mrs. Funmilayo Ransome-Kuti, Mrs. Adenike Ebun, late Hadjia Ladi kwali, Mrs. Ebun Oyagbola, Professor Bolanle Awe; late Mrs Margret Ekpo, late Hadjia Sawaba Gambo, Mrs. Abiola Babatope and host of others readily comes to mind. Some of the women went into the men's territory such as law, medicine, engineering, architecture and all the supposedly male professions. They not only did very well in these fields, some of them topped the class much to the amazement and chagrin of their male counterparts.

Today women are arguing by words and actions that, "what men can do, women can also do or even do better". This is due to the fact that education is now available to both men and women in the country and both sexes are becoming more and more educationally equipped to 
serve the nation in various capacities. It is however, expected that educated women like their male counterparts will also be allowed to render their education - given or endowment services to the nation as workers. Interestingly, professional areas previously regarded as the sole preserve of men are now being invaded by women.

\section{Literature Review}

\subsection{Women and Political Participation}

Despite the campaigns and conferences all over the globe in respect of the need to enhance and promote gender equality in all human spheres, there still exists a wide gap of difference between the level of women and men participation in politics, trade unionism and decision-making in both private and public organizations in Nigeria. To a great extent most of the political institutions and pressure groups in Nigeria are exclusively dominated by men who determine the rules and trends. This glaring imbalance of men domination over women obviously has attracted running comments from scholars and writers especially women who seem to have been tremendously marginalized within the political arena.

The Beijing conference of September, 1995 and the Convention on Elimination of all forms of Discrimination Against Women (CEDAW) articulated issues of concern to women and sought for ways to significantly involve women in societal processes such as governance and also reduce thseir disadvantage and oppression cum less participation in international conferences. However, only twelve countries have women holding 33\% or more seats in the parliament (UNDP Report 2005).

An increasing number of people in the recent years seem to cherish the virtues of women in holding political offices and positions. According to Bucknor - Akerele (2002) the equation is stated in clear language that if women occupy some of the political positions currently occupied by men, the standard of practice on political virtues will rise. In other words, increased women participation in politics will cleanse up the filthy political stable. Politics will certainly become less filthy.

In Nigeria, the performance of women like the Minister of Finance Dr (Mrs) Okonjo -Iweala and Professor Dora Akunyili, former Director-General of NAFDAC (National Agency for Food, Drug, Administration and Control) and later Minister of Information and host of others lend credence to the foregoing line of thought. These women of fame in the course of occupying political offices displayed extreme dexterity and were huge success in their official/national assignments.

With an increasing recognition among international community of women's historic exclusion from the structures of power, global commitment has been made to redress gender imbalance in politics. Women's enhanced participation in governance structure is viewed as the key to redress gender inequalities in society. In this respect, Oyekanmi and Soyombo (2006) seem to have invested formal powers of the women with reckoning, thus suggesting that women are not as powerless or involved as it seems but because they are not well represented at the formal political level. 
Scholars have floated two arguments that have dominated global debate on the promotion of women's political participation. These are the intrinsic and instrumentalist arguments:

The intrinsic school argues for equal participation of women in politics from the human right perspective and the fact that women constitute half of the world population and representation in world democracies. Instrumentalist argument pushed for women's greater participation on the essentialist ground that men and women are different. Women have different visions and concepts of politics owing to their sex and either gender roles as mothers. Therefore, it is assumed that women in politics will bring a special caring focus and female values to politics. According to Oyekanmi and Soyombo (2006), women have emotional power over men and virtually all men aspire to satisfy the women to whom they are beholding.

\subsection{Nigerian Women and Political Structure}

Nigeria women's historic exclusion from political structures and processes is the result of multiple, structural, functional and personal factors. It is therefore, imperative to critically review these constructs and decode the gendered nature of democracy as well as development which pose limitations on women's effective political participation. The elements of enabling environment for women participation in political process and development cannot be discussed and identified without putting current development and political paradigms under consideration. Presently, the main stream of development paradigms based on capitalist relation of production thrives on opportunities created by gender relations for power and profit (Connell, 1987). There is an intrinsic link between women's domestic labour with capital accumulation. As Leacock (1977) puts it, the inequalities between men and women could not be understood in isolation from polarizing tendencies of the capitalist mode of production which places the countries of the third world in a relationship of dependency with the metropolitan centres of the world. Within an equalitarian world order, so called development could not release women from oppression, social economic and political institutions, it merely defines new conditions of constraints.

Another contextual issue in women's participation in political activities relates to the nature of politics in general and the liberal democracy in particular. Democracy has historically served men better than women. Women have been kept outside the public domain of politics as most of the political thinkers and philosophers such as Plato, Aristotle, Rousseau, John Locke, Thomas Hobbes and Hegel considered women fit only for domestic roles in the private sphere and maintained that there was no place for women in politics because of their suitability in caring roles as mothers and wives. The public - private divide remains as the foundation of the various forms of world democracies (Phillip, 1998, Rai 2000).

Some analyst hold the view that due to the emotional power of women to whom men are beholding, men holding important positions in public life invariably defer to the women in their lives in whatever they do with women, thus exercising enormous control over policies from informal perspective. While it is true that women exercise some forms of influence on men at emotional level, it is much more complex trying to determine what the actual level of influence is, and the degree of actuality attributable to the formal and informal process 
respectively (Olaitan, 1998).

\subsection{Male Domination of Women in Politics}

The history of male domination in Nigeria is legendary while the structural and functional constraints faced by women are shaped by social and political relations in the country. Some of the factors are highlighted briefly:

The ideology/patriarchal orientation is a system that rest on male domination. It constructs a hierarchy of gender relations where men are privileged (Eisenstein, 1984). In equal vein, patriarchy has been defined as a familial, social, ideological social that determine what part women shall or shall not play and also the female is everywhere subsumed under the male.

In Nigeria, the gender role ideology and patriarchy place women within the arena of home as mothers and wives and men in the public sphere. In most part of Nigerian society, men are perceived as superior to women and therefore not suitable for political leadership. Rulership is seen as a male affair. The existence of this male domination model results in either women rejecting politics altogether or rejecting male style of politics (Anya, 2003). According to Akinyode-Afolabi and Arogundade (2003), women perception of politics as a dirty game and continued fright at the thought of violence has further alienated them from the mainstream of politics.

Table 1 depicts the level of women marginalization in the political process in Nigeria. From Table 1, in 1999-2003, number of men elected into the House of Representatives was 339 or $94.7 \%$ while women were 21 or $5.8 \%$. In 2007-2011, number of men elected into the House was 333 or $92.5 \%$ and the women were 27 or $7.5 \%$. For senate in 1999-2003, 106 or $97.2 \%$ men were elected as against 3 or $2.8 \%$ women elected. In 2007-2011, the number of men elected into the senate was 101 or $92.7 \%$ while women recorded 8 or $7.3 \%$. This presuppose that while there is steady growth in women participation in political process and representation in developed countries there seems to be no appreciable progress in the developing countries including Nigeria.

Table 1. Summary of Nigerian Men and Women Elected into the National Assembly (1999-2003) and (2007-2011)

\begin{tabular}{|c|c|c|c|c|c|c|c|c|c|}
\hline \multirow[t]{4}{*}{ Position } & \multirow[t]{4}{*}{ No. of Seats } & \multicolumn{4}{|c|}{$(1999-2000)$} & \multicolumn{4}{|c|}{$(2007-2011)$} \\
\hline & & \multicolumn{4}{|c|}{ House Elected } & \multicolumn{4}{|c|}{ Senate Elected } \\
\hline & & \multicolumn{2}{|c|}{ Men } & \multicolumn{2}{|c|}{ Women } & \multicolumn{2}{|c|}{ Men } & \multicolumn{2}{|c|}{ Women } \\
\hline & & No & $\%$ & No & $\%$ & No & $\%$ & $\mathbf{N}$ & $\%$ \\
\hline House of Rep. & 360 & 339 & 94.2 & 21 & 5.8 & 333 & 92.5 & 27 & 7.5 \\
\hline Senate & 109 & 106 & 97.2 & 3 & 2.8 & 101 & 92.7 & 8 & 7.3 \\
\hline
\end{tabular}

\subsection{Women and Trade Union Movement}

Women being so professionally involved almost in all occupational sphere raises the question as to whether or not they should participate in Trade Union Movement. Since the education of 
women has come to stay not only in Nigeria but globally, a feat facilitated by Government free education programme, it is only logical to expect that the female products who passed through the school system would be better equipped to serve the nation in various capacities as workers, experts and policy makers. If this fact is accepted, it is not abnormal for women to participate in trade unionism - the instrument for effective bargaining, improvement of working conditions and the creation of cordial relationship between the employees and the employers. However, being logical is one side of the coin and being practical is another dimension. The focus of this paper is to assess the extent of women participation in Nigerian Trade Union Movement. To address the question, there is need to examine the pros and cons of women participation in Trade Union Movement. Trade Union as a mass organization is regarded as a family of workers. Trade Union knows no tribe, sex, religion or ethnic hegemony. Since conjugal families comprise both father and mother it is also expected that to give Trade Union this family outlook, both men and women should take active interest and effective participation in Trade Unionism.

Furthermore, commonsense demands that as women work side by side with men in various work places and institutions, it is necessary that women take actively part in Trade Union Movement, so as to be able to put across their views and needs i.e. professional and other needs peculiar to women for deliberation at trade union meetings, congresses and conferences. It is important to note that in some advanced countries, women have even become professional trade unionists besides active participation as working unionists. In other words, it is believed that women participation in Trade Union Movement will make the needs peculiar to women be better catered for by Trade Unions.

In Nigeria today, a good number of women are still reluctant to identify themselves with trade union activities; only very few of them are participating actively as professionals and trade union activists. This is due to the fact that women like men belong to the group of creatures referred to as "homo-sapiens", yet there are differences in psychological and physical make-up of the two groups. This human differences no doubt affect the way and manner each sex perceives and reacts to various work variables or situations, terms and service conditions. In equal vein, women appear better organized to put across their peculiar needs and requirements within the confines of their occupational settings. In other words, the democratic principles will be enhanced if women are allowed to participate in Trade Union Movement so as to put across views that would be particularly helpfully or useful to women's cause and interest.

\subsection{Strategic and Socio-psychological Roles of Women in Unionism}

In order to see swifter progress concerning women participation in trade unionism, several factors must come together. More women must develop their skills and demonstrate their commitment to the labour movement (Kaminski and Yakura, 2008). Women are also less likely to be tolerant of unethical business practices and unscrupulous negotiation tactics (Swamy et al. 2001; Volkema 2004; Kaminski and Yakura, 2008), attitudes that are consistent with labor union goals. Women are also more likely than men to be transformational leaders, which is characterized by being a role model, inspiring others, strategic thinking, innovation, 
and mentoring and developing others in the organization (Kaminski and Yakura, 2008; Eagly, Johannesen-Schmidt, and van Engen 2003).

Moreover, the International Labour Organisation (ILO) postulates that Unions should evolve strategies that will consistently encourage equal representation of both men and women in leadership positions because of the following reasons (Folorunsho, 2011):

1. women account for an increasing proportion of the workforce;

2. to be credible and strong, unions must address the priority concerns of its current and potential members, and women concerns are numerous;

3. to be credible to women, unions must demonstrate that gender equality is an integral part of their own policies and structures;

4. growing numbers of women workers are standing up for their rights and seeking support for their rights;

5. women members are positively changing the way unions work and improving the image and influence of unions;

6. the promotion of gender equality helps unions strengthen and reaffirm their key role as agents of social change;

7. the promotion of gender equality provides common grounds for unions to forge alliances with other social actors.

Psychologically, women appear to have more concern for the welfare of others. Thus it is clear that since Trade Unionism is geared towards bringing improvement in the welfare of the working class, women appear to be very necessary ingredients towards maximizing the realization of the welfare objectives of Trade Unionism. To discourage women from participating in Trade Union Movement is to deprive the working masses especially men this much needed and vital feminine touch and colouration. Women are more cooperative, interdependent, and concerned about the welfare of the entire group (Schwartz and Rubel 2005; Kaminski and Yakura, 2008).

It is a common believe that behind every successful man, there is a woman at the background. It would not be out of place if women are allowed to participate alongside men in Trade Union Movement in order to motivate men and complement their contributions towards overall benefit and welfare of the working group. Furthermore, women participation will assist in the excesses of men's aggressiveness which could at times run off-hand and destroy rather than build and create room for responsible unionism. Based on experiences, many rash and destructive actions and decisions could have been carried out by male unionists but for the timely intervention and advice of their less aggressive wives and female membership. Since Trade Unionism appears to be crisis-prone and problem loaded, women Trade Unionists may not be very good problem solvers or crisis managers or key post holders within the Trade Union. It is a known fact that women are peace makers and generally have negative attitude towards risk-taking than men. This weakness could act as a clog in the 
wheel of progress within Trade Unions if women hold militant and high administrative posts in Trade Unions and are given opportunity to manage crises. It must be emphasized that militancy and risk-taking are very important factors for the survival and progress of Trade Union organization especially in the course collective bargaining. Trade Unionism feeds on risk-taking and militant radicalism in its quest to achieve its goals and objectives. When it is considered that a good number of the working-class ladies are married, one would easily appreciate another possible source of problem which may arise when married women participate in Trade Union Movement. One such problem is associated with pregnancy and child birth. During these periods, the Trade Union women activists may not be able to render full and active services to the Trade Union.

Besides, such married women Trade Unionists may sometime, run into the difficulty of serving two masters at the same time. For example, the demands of her husband may run counter to that of her Trade Union activities and vice versa, hence one of the two is bound to suffer. To obey the husband at the expense of the Trade Union participation is to incur the criticisms of her fellow unionists and the Labour Movement at large. She will thus be labeled as an apathetic and disloyal unionist. On the other hand, if she decides to obey the union at the expense of her husband, she will inviting marital disharmony in her home which sooner or later may affect her overall activities in both the union and her matrimonial home.

Participation in Trade Unionism involves a lot of meetings and movements and only a few husbands especially in Nigeria can be tolerant and allow their wives to so globe-trot all in the name of Trade Unionism.

From the foregoing shortcomings and problems highlighted in women participating in Trade Union Movement, it would appear that while it is democratically reasonable and logical to allow women participate in Trade Union Movement, they should not frankly speaking be allowed to hold posts or be giving positions that would run counter to their peculiar traits or make-up and at extreme threaten their matrimonial homes. On the strength of this viewpoint, the salient traits of women's superiority over men should act as a practical guide in assigning duties to women participating in Trade Union Movement, as females are superior in verbal fluency, perceptional speed and dexterity. Thus women in our opinion can be called upon to serve the Unions as Secretaries and Treasurers; while men should hold risk-taking, leadership and hard-bargaining positions that go along with militancy to enable employers concede to unions’ demands.

\section{Conclusion}

By and large, Nigerian married women appear very much occupied in domestic matters and other engagements; it would therefore be advisable that efforts should be made by women in general irrespective of status to devote more time to trade union activities and come out openly to take up positions as professionals and working trade unionists. This no doubt will serve as a challenge to others who have apathetic approach to labour matters.

In conclusion, if we do not allow women to participate in Trade Union Movement for reasons already adduced, at least they should be allowed to participate because this is the age of 
women liberation globally and Nigerian women cannot be an exception. We should give women a chance, for there is a popular saying that what men can do, women can also do or even do better. Husbands should allow their wives full participation in Nigerian Trade Union Movement like their counterparts in other advanced countries. The working class men should always encourage working women and give them opportunity to participate fully in all trade union activities. Men should not monopolize union positions as women are also part and parcel of the Trade Union Movement and should be carried along the same level playing ground as their male counterpart.

\section{References}

Ademiluyi, I.A., \& Imhonopi, D.F. (2010). Trade Union Dynamism in a Belligerent State-Nigeria, Between 1980-2007. Journal of Economics and Engineering, 4: 44-50.

Adewumi, F. (1997). Trade Unionism in Nigeria: Challenges of the $21^{\text {st }}$ Century, Lagos: Friedrich Ebert Foundation.

Akiyode-Afolabi, A., \& Arogundade, L. (2003). Gender Audit 2003 Election and Issues in Women's Political Participation in Nigeria. Lagos: Women Advocates Research and Documentation Centre (WARDC).

Anya, O. (2003). Women and Politics in Nigeria's $4^{\text {th }}$ Republic in the Constitution. A Journal of Constitutional Development. (Centre for Constitionalism and Demilitarization) (CENCOD) Lagos: Panaf Press,

Bucknor-Akerele, K. (2002). Travails of Nigerian Women in Politics in Afolabi, O (ed) Women and Gender Equality: For a better society in Nigeria. Third Annual Lecture of the Leaving Club International.

Cornell, R.W. (1987). Gender and Power, Cambridge: Polity Press.

Eagly, A. H., Johannesen-Schmidt, M.C., \& van Engen, M.L. (2003). Transformational, transactional, and laissez-faire leadership styles: A meta-analysis comparing women and men. Psychological Bulletin,129: 569-591. http://dx.doi.org/10.1037/0033-2909.129.4.569

Eisenstein, Z. (1984). Contemporary Feminist Thought, London: Urwin.

Folorunsho, O. (2011). The Role of Women in Trade Unions and Nation Building. www.pengassan.org. Accessed in August.

Imhonopi, D., \& Urim, U.M. (2011). The Development of Labor Movements and State Interference: The Nigerian Experience. Journal of Sustainable Development in Africa, 13(2): 236-252.

Kaminski, M, \& Yakura, E.K. (2008). Women’s Union Leadership: Closing the Gender Gap. The Journal of Labour and Society, 11: 459-475.

Knudsen, R. (1968). Employment of Women, Paper Presented at International Seminar on employment of Women (Regional Trade Union Seminar) held in Paris, $26^{\text {th }}-28^{\text {th }}$ November. 


\section{Macrothink}

Journal of Management Research

ISSN 1941-899X

2012, Vol. 4, No. 1: E17

Leacock, E. (1997). Reflection on Conference on Women and Development: the Complexity of Change,, Wellesley Editorial Committee, Chicago University Press.

Mulvey, C. (1978). The Economic Analysis of Trade Unions, Oxford: Martin Robertson and Co. Ltd.

Odi, M. (2010). The Power of Women's Collective Action. Lagos: Muhamsaid Press.

Okogwu, G.C. (1996). Decentralization of Trade Unions: Implications for Industrial Relations Practice in the Banking Industry, Paper Present at NBEG's $2^{\text {nd }}$ National Seminar on Industrial Relations, held in Lagos.

Olaitan, W. A. (1998). Women in Politics in Nigeria in Amedu Sesay and Adetanwa Odebiyi (eds) Nigeria Women in Society and Development. Ibadan: Dokun Publishing House.

Otobo, D. (1996). The Theory and Practice of Industrial Relations and Trade Unionism in Nigeria: A General Theoretical Framework, Paper Presented at NBEG's $2^{\text {nd }}$ National Seminar on Industrial Relations, held in Lagos.

Oyekanmi, A.D., \& Soyombo, O. (2006). Factor Millitating Against Women Participation in Politics in Nigeria, Society and Governance: The Quest for Legitimacy in Nigeria, Oyekanmi, A.D. and Soyombo, O. (Ed). Lagos: Irede Press.

Phillips, A. (1998). Feminisms and Politics. Oxford: Oxford University Press.

Rai, M.S. (2000). International Perspective on Gender and Governance, Great Britain: McMillan Press.

Schwartz, S. H., \& Rubel, T. (2005). Sex differences in value priorities: Cross-cultural and multimethod studies. Journal of Personality and Social Psychology, (89): 1010-1028. http://dx.doi.org/10.1037/0022-3514.89.6.1010

Swamy, A., Knack, S., Lee, Y., \& Azafar. O. (2001). Gender and corruption. Journal of Development Economics 64: 25-51. http://dx.doi.org/10.1016/S0304-3878(00)00123-1

Tar, U.A. (2009). Organised labour and democratic struggles in Nigeria. Information, Society and Justice, 2(2): 165-181.

United Nations Development. (2005). Human Development Report.

Volkema, R. J. (2004). Demographic, cultural, and economic predictors of perceived ethicality of negotiation behavior: A nine-country analysis. Journal of Business Research, 57:69-78. http://dx.doi.org/10.1016/S0148-2963(02)00286-2 